\title{
TWO VALIDATIONS IN BACCHARIS (ASTERACEAE: ASTEREAE) ${ }^{1}$
}

\author{
LEONARDO PAZ DEBLE ${ }^{2}$ ANABELA SILVEIRA DE OLIVEIRA-DEBLE ${ }^{3}$
}

\begin{abstract}
In this paper are made the validations of Baccharis lymanni and B. nebulae. Comments, geographic distribution and allied taxa of these species are given.

Kew words: Baccharis lymannii, Baccharis nebulae, validations, Astereae, Asteraceae.

\section{RESUMO}

[Duas validações em Baccharis (Asteraceae: Astereae)].

Neste artigo são feitas as validações de Baccharis lymannii e B. nebulae. São fornecidos comentários, distribuição geográfica e distinção dos táxons relacionados a estas espécies.

Palavras-chave: Baccharis lymannii, Baccharis nebulae, validações, Astereae, Asteraceae.
\end{abstract}

\section{INTRODUCTION}

Two southern brazilian species of Baccharis are not validly published because in the original protologue the authors cite two exsiccates as type. The validation and comments of both species are made below.

\section{RESULTS}

\section{Validation of Baccharis lymanii}

Barroso (1976) proposed Baccharis lymanii from Santa Catarina state (Brazil), but the author cites in original description: "Holótipos: SC Campo Alegre a $900 \mathrm{~m} \mathrm{s.m.} \mathrm{leg.} \mathrm{L.} \mathrm{B.} \mathrm{Smith} \mathrm{e}$ Klein 7.461 (9.11.1956) ? RB. HBR; ibidem, campo alpino Morro Iquererim a $1.300-1.500$ m s.m. leg. L. B. Smith e Klein 7.418 (8.11.1956)

? RB. HBR." According to article 37.1 of the ICBN (2006), the name was not validly published, because two collections are designated as "Holotype" (see ex. 1). The species is validly published and a original collection is selected as Holotype.

1 Recebido em 22-11-2008 e aceito para publicação em 17-01-2009.

2 Biólogo, Dr., anabela.biol@gmail.com

3 Biólogo, Dr., deble.biol@gmail.com
Baccharis lymanii G. M. Barroso, sp. nov.

Validating description and diagnoses: Rodriguesia 28 (40): 165. 1976. Typus: BRAZIL, Santa Catarina, Campo Alegre, ?, 09.XI.1956, L. B. Smith \& R. M. Klein 7.461. Holotypus RB! Isotypi HBR! LP!

We selected this material as holotype because it is a female exemplar, the leaves are clearly opposite or almost opposite and for the abundant capitulescence in leaf axil, in accordance with the original description.

Distribution \& Habitat: Baccharis lymanii is restricted to highlands in southern Brazil (Paraná, Santa Catarina and Rio Grande do Sul states), at altitudes between 900-1.800 m.

Comments: Baccharis lymanii belongs to section cylindricae Heering, series Axillares Giuliano, being near to $B$. pauciflosculosa DC. but differs of this species by opposite or almost opposite leaves, with obtuse or acute margin teeth (vs. alternate leaves, with rounded margin teeth), and by female capitula with 7-8 flowers (vs. 2-4). Baccharis lymanii is also related with $B$. angusticeps Dusén; this species, however, showed attenuate leaves, in petiole (vs. sessile) and only 1-3 flowers in the female capitula (vs. 7-8). 


\section{Validation of Baccharis nebulae}

Baccharis nebulae was recognized as a new species by Malagarriga and Hatschbach that sent for Barroso two exsiccates (Hatschbach 17.311 and 25.747) to publication by her (comm. pers. of the last author). Barroso, however, determined the material as B. grandimucronata. Recently, Oliveira \& Marchiori (2005) described them as a new species. In the protologue, however, these authors cite two exsiccates as type. According to article 37.1 of the ICBN (2006), the name was not validly published (see ex. 1). Baccharis nebulae is now published and comments about this species are made.

Baccharis nebulae Malag. \& Hatschbach ex A. S. Oliveira, sp. nov.

Validating description and diagnoses: Balduinia 5: 11. 2005. Typus: BRAZIL, Paraná state, Campina Grande do Sul, "pico Caratuva, topo do morro, capítulo alvacento, ?, $1.950 \mathrm{~m}$ ", 05.X.1967, G. Hatschbach 17.311. Holotypus MBM 6.837!

We selected this material as holotype because it is the original type, selected by Malagarriga and Hatschbach. The holotype showed clearly obovate leaves with margin revolute and entire leaves, as well as corymbiform capitulescence, with few capitula (8-10). These morphological characteristics are important to distinguish the taxon.
Distribution \& Habitat: Baccharis nebulae is endemic of the highlands of east Paraná state and northeast of Santa Catarina state, at altitudes between $1.000-1.950 \mathrm{~m}$.

Comments: Baccharis nebulae is very nearly related with the alopatric species $B$. grandimucronata Malag. This species, however, showed acute elliptic to oblanceolate leaves, with serrate, not or slightly revolute margin (vs. rounded to slightly acute obovate to oblanceolate leaves, with entire, rarely crenate or 1-3 teeth, revolute margin) and capitulescence with many capitula (40-200 vs. 8-25).

\section{ACKNOWLEDGMENTS}

The authors thank José Newton Cardoso Marchiori for the valuable comments.

\section{REFERENCES}

BARROSO, G. M. Compositae-subtribo Baccharidinae Hoffman. Estudo das espécies ocorrentes no Brasil. Rodriguesia, v. 28, n. 40, p. 3-273, 1976.

OLIVEIRA A. S., Marchiori, J. N. C. O gênero Baccharis Linnaeus, seção Oblongifoliae DC. (Asteraceae-Astereae) no sul do Brasil. Balduinia, Santa Maria, n. 5, p. 6-15, 2005.

MCNEILL, J., BARRIE F.R., BURDET, H.M., DEMOULIN, V., HAWKSWORTH, D.L., MARHOLD, K., NICOLSON, D.H., PRADO, J., SILVA, P.C., SKOG, J.E., WIERSEMA, J.H., TURLAND, N.J. (eds). ICBN - International code of botanical nomenclature (Viena Code). Regnum Veg. 146, 2006. 